\title{
Popular Culture, English Out-of-class Activities, and Learner Autonomy among Highly Proficient Secondary Students in Hong Kong
}

\author{
Hoi Wing Chan \\ Division of Language and Communication, Hong Kong Community College, The Hong Kong Polytechnic University, Hong Kong, China
}

Copyright@2016 by authors, all rights reserved. Authors agree that this article remains permanently open access under the terms of the Creative Commons Attribution License 4.0 International License

\begin{abstract}
This paper reports on how and why proficient learners of English in Hong Kong participated in popular culture, out-of-class activities, with an emphasis on their development of learner autonomy. Autonomy in language learning is defined as an individual's ability and responsibility to take charge of his or her own learning [1]. Out-of-class learning plays an important role in language learning and learner autonomy [2]. However, to most Hong Kong students, opportunities to learn English outside of classroom may not be obviously found but they do exist at a low cost, for example, popular culture like English movies, free English TV channels, online resources, social networking [2-4]. Most local learners seldom engaged in actual autonomous practices but they must seize the chances to practise the target language $[5,6]$. Thus, the study aimed at exploring how students can make better use of popular culture, out-of-class learning and foster greater learner autonomy in the local context. Six highly proficient secondary school students who reported to have participated in out-of-class learning were selected to join this largely qualitative multiple-case study. By way of semi-structured interviews and language learning journals, the study found that the case participants mainly engaged in self-initiated, interest-driven out-of-class learning, through which they improved their school performance and started to internalize English learning for their personal purposes and develop learner autonomy. It is also suggested that out-of-class learning and school performance promoted the growth of each other. Teachers should recognize the use of interest-driven, popular culture out-of-class activities to further establish the link between out-of-class and classroom-based learning.
\end{abstract}

Keywords Learner Autonomy, Self-directed Learning, Lifelong Learning, Out-of-class Learning, Second Language Acquisition

\section{Introduction}

\subsection{Background of the Study}

In Hong Kong, a largely Cantonese-speaking society, opportunities to use English were mainly limited to formal, academic contexts. Sanctions against the use of the language in students' social contexts were common [7]. Also, English language was a core subject in the university admission public examination. Immersed in exam-oriented learning, most local learners were unaware of the importance of out-of-class learning and learner autonomy [8]. However, to further improve the language and to adapt to the lifelong learning environment, local students had to overcome the constraints and engage in out-of-class learning. This study aimed at investigating how highly proficient English learners took advantage of out-of-class learning and developed learner autonomy. This paper, in particular, reports on the case participants' engagement in popular culture related out-of-class learning within their personal context. The findings hope to shed light on ways to maximize out-of-class learning and its role in learner autonomy.

\section{Literature Review}

\subsection{Learner Autonomy and Out-of-class Learning}

With a rise in the trend of lifelong learning and learner-centered language education, learner autonomy is one of the focuses of second language teaching and learning $[9,10]$. According to Holec [1], autonomous learners should have the ability and responsibility to decide the aims of learning, define the learning content and progress, choose the appropriate methods to learn, monitor their learning process, and finally, evaluate the learning outcome. Out-of-class learning plays a major role in developing learner autonomy 
$[4,11]$ and improving language proficiency $[12,13]$.

Out-of-class learning can be categorized into three types: "self-instruction" (for language learning only), "naturalistic learning" (with minimal attention to language learning), and "self-directed naturalistic learning" (creation of communication opportunities with the intention of language learning) [4, 14]. Self-directed naturalistic learning is common because learners can enjoy interest-based activities and learn the language simultaneously [4, 14]. Thus, English-medium popular culture and social networking in globalized online space (e.g. video/picture sharing sites) have attracted researchers' attention [2, 8, 15]. More studies are needed to examine the purpose and the role of out-of-class learning in the course of learner autonomy development in the local context.

\subsection{Popular Culture and Out-of-class Learning in Hong Kong}

To most Hong Kong students, opportunities to learn English outside of classroom may not be obviously found but they do exist at a low cost. English movies and free English TV programmes are very popular among young learners [2, 3]. Most local teens and young adults also engage in participatory use of English through online, digital media such as online games, social networking (e.g. instant messaging, blogging, Facebook), video, song, or text sharing platforms (e.g. YouTube, Instagram), in English or in a code-mixing way $[2,8,15]$. The online digital media offers more authentic, interactive affordances for local students to use and learn English [15]. In this paper, popular culture refers to the wide scope of popular media, including novels, music, films, digital games, TV programmes and online social media [2]. Engagement in popular culture nowadays occupies a teen's daily life and it provides language learners a possible media to practise the target language when facing the constraints of classroom learning [2]. Yet, several studies revealed that most local students preferred private, receptive to productive activities [16-19]. For example, in Chik's [20] study, a case participant focused on watching TV programmes while participants in Hyland's [16] study enjoyed listening to songs, browsing the Internet, watching English TV channels.

Furthermore, mainly instrumentally motivated, most local learners face learning constraints like lack of motivation, heavy reliance on teachers, social sanctions against the use of the language, exam-oriented learning, heavy school workload and few autonomous learning skills and experiences [13, 14]. Although studies showed that most local learners were positive towards learner autonomy, interestingly, with a weak sense of learner autonomy, they seldom engaged in actual autonomous practice, which was not required at school [e.g. 5, 6, 8].

As studies found that "Good" language learners usually engage more in out-of-class learning and practice the target language outside of class more often [23], how proficient Hong Kong English learners approached popular culture as a form of out-of-class learning would have implications on helping students overcome constraints and develop learner autonomy. While past studies already focused on the patterns and constraints of out-of-class learning, how and why proficient students took advantage of popular culture related out-of-class activities and their approach to overcoming obstacles worth further investigation. Also, students' participation in popular culture, as a readily available form of out-of-class learning, needs to be further investigated in a contextualized, qualitative study, with an aim to explore their role in learner autonomy.

In this paper, two major research aims were to be discussed. How and why the case participants involved in popular culture related, out-of-class learning was to be examined. The role of this particular type of out-of-class learning in learner autonomy development was also explored.

\section{Methodology}

\subsection{Data Collection and Analysis}

To understand the "hidden" participation of popular culture outside of classroom, a qualitative multiple-case design was adopted (This paper focuses on part of the findings of the author's PhD study; see [24] for the author's dissertation.) to understand the case participants' introspective insight on their learner autonomy development. A survey was administered to select six highly proficient case participants who reported to have engaged in out-of-class learning often (see [25] for the results of this phase). Next, the six case participants participated in two semi-structured interviews conducted in Cantonese, which was their first language. They were invited to share their English usage during secondary education, both required and voluntary, from their school context to their home and community situations. To find ways to maximize out-of-class learning, the interviews aimed at understanding how they actively looked for the opportunities to use English, monitored their proficiency, and overcame challenges. To better understand their learner autonomy development, they were also asked to reflect on their autonomous practices. The data in the survey, and interview transcripts were coded and analysed through thematic approach to identify categories and themes [26, 27].

\subsection{Profiles of the Case Participants}

Six participants, Ada, Carl, Elsa, Jo, Mandy, and Terry (pseudonyms), aged 20-21, all obtained Grade B (or, Level 5) or above in the English language examination in the Hong Kong Certificate of Education Examination (HKCEE) and in the Use of English (UE) examination in Hong Kong Advanced Level Examination (HKALE), which were regarded as the entrance examination to local universities. As the study focused on the participation of out-of-class 
learning, locally educated, Hong Kong born, native Cantonese-speaking participants who were highly proficient in English were invited to join the study. During the data collection period, they were second year university students majoring in English or English language education. In the following sections, how the case participants made use of popular culture to learn the language and fostered greater learner autonomy will first be discussed, followed by pedagogical implications for ways to maximize English-medium popular culture for language learning and strengthen learner autonomy.

\section{Results and Discussion}

In Hong Kong, English is largely used in written, academic and formal contexts. Also, facing social sanctions against the use of the target language in social situations, local students lack opportunities to use the target language in their everyday life. English-medium popular culture helps local students, including the six case participants, overcome the constraints of classroom learning $[2,15]$. For instance, they loved watching English-medium movies, e.g. The Holiday, Lost in Translation, and TV series, e.g. CSI, House, Friends, and Desperate Housewives. While most local learners also enjoyed and improved the language through these receptive activities [16-19], the case participants made a further effort to maximize English-medium popular culture out-of-class activities.

\subsection{Personalization: Language Strategies and Personal Interest}

Through participation in English-medium popular culture, the case participants improved their English skills, including vocabulary building skills, reading and listening skills [28]. The important point is that all case participants stressed that they made a voluntary effort and chose a strategy to monitor their language skills when watching their favourite programmes, for example:

I made an effort to comprehend the English. I tried my best to comprehend the content. I only read subtitles when in need. (Ada, interview 1)

I just let the movie go and paid attention to the new vocabulary. Then I watched it again to study the new words and jotted down on my notebook. (Elsa, interview 1)

Although their strategies of language learning are quite traditional, Ada and Elsa stressed that they utilized their own effort to control and design the language learning task, revealing a sense of ownership of language learning. To keep themselves engaging in the popular culture, out-of-class learning, Terry and Mandy personalized their effort to satisfy their own interests:

When one listened to the jargon about tennis games, one could understand the game gradually. You would then feel more interested in listening to the commentary, history, and players' feelings after winning the game. (Terry, interview 1)

[I paid attention to] how they (the actors and actresses in a movie in which some speak the British variety and some use the American) articulate, pronounce. I also found that their tone is flat... and it was difficult to learn. [...] I paid attention to the use of words too... sometimes the difference in the vocabulary between British and American English, too. (Mandy, interview 1)

Terry learned the jargon for enjoying sports programmes. Mandy was interested in language varieties and focused on this particular aspect when watching the movie. Their participation was initiated by their own interest in sports and movies. Through popular culture, their sense of progress in their language proficiency and the interest in the leisure activities grew simultaneously, fostering greater learner autonomy. They, in particular, stressed that they enjoyed English-medium popular culture leisure activities as the primary purpose instead of language learning, illustrating the participation of self-directed naturalistic learning [4]. To Jo, enjoyment was the main reason for her to engage in popular culture, out-of-class activities:

It was a rather relaxing activity. It was not a harsh or formal activity which required a high level of concentration. I could choose the time to do it-when I felt comfortable. Although I didn't have any interaction, I did enjoy and engage in the activity. (Jo, interview 1)

\subsection{Active Exploration of More Learning Opportunities}

Furthermore, two case participants successfully took control of their learning environment and extended their receptive, entertainment activities into productive language use.

At first, Carl only loved reading blogs in English; then he established his blog to improve his writing and wrote "almost one passage per day" (data from the survey). The visibility of his blog to his friends motivated Carl to closely monitor his accuracy [29]:

I must proofread (the blog). When I fell asleep, suddenly I found that I had made a mistake, like, missing an 's' after plural nouns. I would wake up, turn on my computer, and correct it. Then I went to bed again ...I didn't allow myself to have any mistakes that I was aware of. I would correct all mistakes that I could spot. (Carl, interview 1)

His behaviour was in line with the students' language practice in Hafner and Miller's [5] study on a YouTube digital video project. The students worked for the best as an extended group of Internet users would read their works. After some time, Carl's writing was accepted and recognized 
by other Internet users:

I read from the comments left by others. At the beginning, other bloggers mainly read the content. Later, they said, my writing was getting difficult for them to understand. I could then see my improvement. (Carl, interview 1)

Through writing his blog, he developed ownership of English: "I thought that English is very global. There is no rule over who can use and who cannot use it." The out-of-class, online platform, where Internet users were able to interact in the target language with low barriers, helped Carl transform himself from a reader to a contributor. Being a blogger, he then realized that he had the right to use English, including in the school context, where using English in non-classroom situations was deemed as being arrogant. The popular culture related out-of-class learning activities helped Carl overcome the social sanctions he faced at school [2]. Furthermore, through his own way of practices (writing his blog and monitoring his proficiency), his schoolwork improved. The success of this self-initiated autonomous learning reinforced his belief in his self-efficacy, improved language abilities, built more favourable learner identities, and most importantly, gained positive autonomous learning experiences.

Jo loved reading Agatha Christie and she wanted to "know the differences between English and Chinese versions and learn some more vocabulary": "I did copy some passages and I intentionally used the sentence structures and vocabularies (learned in the novels) in my composition.” Her experiments with new words and structures were appreciated by her Native English Teacher (NET) at school. A "strong" sense of ownership of the reading was formed: "I could rely on myself to learn something and I could apply it too. I had a great sense of satisfaction.”

The out-of-class, English-medium popular culture activities of Carl and Jo eventually benefited their schoolwork. Largely instrumentally motivated, the case participants received recognition at school through their own approach of learning. This strengthened the link between the formal English learning and out-of-class learning, which is the favourable outcome of out-of-class learning suggested by Reinders [30].

Through the participation in popular culture related out-of-class activities, the case participants illustrated their various degrees of control of their learning methods and personal, informal context for English learning. The positive feedback received at school encouraged their active exploration of the unstructured out-of-class context [31]. This showed how out-of-class learning and formal English learning at school worked together to foster the case participants' language skills and autonomy.

\subsection{Discussion and Analysis}

By disclosing their experiences with English-medium popular culture, the case participants revealed how and why they engaged in this type of out-of-class learning. Facing similar constraints like social sanctions against the use of English in daily situations and exam-oriented learning as other local learners, the six case participants wanted to satisfy their personal interest and joined English-medium popular culture, in their personal, out-of-class context. The emphasis on enjoyment and personal value helped them overcome constraints. To know more about their hobbies and enjoy their free time, they made an effort to improve the language through personalized strategies (e.g. avoiding reading subtitles, studying vocabulary). With higher language proficiency, they enjoyed the English-medium popular culture better and in turn, they were more motivated to join popular culture, out-of-class activities.

Some of the case participants further invested in the out-of-class learning because of the improvement in schoolwork. As seen from the cases of Carl and Jo, the instrumental nature of schoolwork, in fact, promoted the participation in interest-driven popular culture related out-of-class learning. At the secondary level, schoolwork and out-of-class learning contributed to the growth of each other. This further motivated the case participants to engage in productive activities, different from the preference of the majority of the local learners to receptive activities [e.g. 21], and established the identity of an English user. The positive cycle supported a spiral growth of interest in popular culture, language proficiency, out-of-class learning and schoolwork.

This study also revealed that English-medium popular culture activities were a starting point for local learners to develop learner autonomy. English-medium popular culture activities (e.g. watching English TV series, online digital media, social networking) not only provided the case participants with an additional learning opportunities [2] but also a context more conducive for self-learning [4]. Popular culture and the platform itself were popular among most young learners. Through the unstructured, popular culture related, interest-driven, out-of-class learning, the case participants started to appreciate their language proficiency through self-evaluation, which promotes self-regulation processes [32, 33]. They demonstrated their involvement in the learning environment and control of their learning path, as a form of learner autonomy, to varying degrees [34, 35]. This new experience of taking control of the learning environment is essential for the growth of learner autonomy [22]. Most importantly, this interest-driven out-of-class learning, associated with English-medium popular culture, was the very first step for the case participants, who were largely instrumentally motivated, to internalize English learning to achieve personal purposes (e.g. to satisfy their interest, to communicate with other Internet users), rather than simply for examinations. At this level, their learner autonomy started to take root when they took part in interest-based, popular culture related, out-of-class activities. 


\section{Implications and Conclusion}

The present study found that the case participants were more motivated to participate in and explore English-medium popular culture out-of-class activities, which were related to their interests; this also served as the starting point for the fostering of greater learner autonomy. English teachers should introduce interest-based English-medium popular culture activities in the classroom and recognize the role of English-medium popular culture out-of-class learning in school performance. After examining their students' language needs and interests, teachers can design interest-driven classroom learning materials, together with the use of mobile applications and social media platform, to motivate students to explore more out-of-class opportunities independently.

As now most teenagers live in the digital world, English teachers should be more open to the use of mobile applications, as well as online, interactive activities (e.g. online gaming, social networking sites, photo-sharing platform), in formal and informal English teaching. Through well-designed, professional development workshops, English teachers should learn more about the pedagogical use of the globalized online space and their facilitative role in language classroom $[5,8]$.

In this study, out-of-class learning in the form of English-medium popular culture, was not yet a compulsory part of the case participants' English learning. Although some established a link between formal English learning and their enjoyment in popular culture, out-of-class learning, they did not take full advantage of this form of out-of-class learning. Future studies should focus on how to help local learners make good use of unstructured popular culture resources in their personal contexts, especially online resources, to foster learner autonomy and gain the right to use the language for their own interest.

\section{Acknowledgements}

This paper is based on the author's $\mathrm{PhD}$ dissertation and focuses on part of the findings; see [24] for the author's dissertation.

\section{REFERENCES}

[1] Holec, H. (1981). Autonomy and foreign language learning. Oxford: Pergamon.

[2] Chik, A. (2015). Popular culture, digital worlds and second language learners. In J. Rowsell \& K. Pahl (Eds.), The Routledge Handbook of Literacy Studies (pp. 339 - 353). London: Routledge.

[3] Benson, P. (2011a). Language learning and teaching beyond the classroom. In P. Benson \& H. Reinders (Eds.), Beyond the language classroom (pp.7-16). Basingstoke, Palgrave Macmillan.
[4] Benson, P. (2011b). Teaching and researching autonomy in language learning (2nd ed.). Harlow, England: Longman.

[5] Hafner, C. A., \& Miller, L. (2011). Fostering learner autonomy in English for Science: A collaborative digital video project in a technological learning environment. Language Learning \& Technology, 15(3), 68-86.

[6] Toogood, S., \& Pemberton, R. (2007). Support structures for self-access learning. In A. Barfield \& S. H. Brown (Eds.), Reconstructing autonomy in language education: inquiry and innovation (pp. 180-195). New York: Palgrave Macmillan.

[7] Li, D. C. S. (2011). Improving the standards and promoting the use of English in Hong Kong: Issues, problems and prospects. In A. Feng (Ed.), English language use and education across Greater China (pp. 95-113). Clevedon: Multilingual Matters.

[8] Chik, A. (2011). Digital gaming and social networking: English teachers' perceptions, attitudes and experiences. Pedagogies: An International Journal, 6(2), 154-166.

[9] Little, D. (2007). Language learner autonomy: Some fundamental considerations revisited. Innovation in Language Learning and Teaching, 1(1), 14-29.

[10] Little, D. (2008). Knowledge about language and learner autonomy. In J. Cenoz \& N. H. Hornberger (Eds.), Encyclopedia of language and education (2nd ed., Vol. 6, pp. 247-258). New York: Springer.

[11] Oxford, R. L. (2003). Toward a more systematic model of L2 learner autonomy. In D. Palfreyman \& R. C. Smith (Eds.), Learner autonomy across cultures: Language education perspectives (pp. 75-91). New York: Palgrave Macmillan.

[12] Norton, B., \& Toohey, K. (2001). Changing perspectives on good language learners. TESOL Quarterly, 35(2), 307-322.

[13] Reinders, H. \& Loewen, S. (2013). Autonomy and language learning behavior: The role of student initiation and participation in L2 Classrooms. Study in English Language Teaching, 1(1), 1-7.

[14] Benson, P. (2001). Teaching and researching autonomy in language learning. Harlow, England: Longman.

[15] Benson, P., \& Chan, N. (2010). TESOL after YouTube: Fansbbing and informal language learning. Taiwan Journal of TESOL, 7(2), 1-23.

[16] Hyland, F. (2004). Learning autonomously: Contextualising out-of-class English language learning. Language Awareness, 13(3), 180-202.

[17] Littlewood, W., \& Liu, N. F. (1996). Hong Kong students and their English. Hong Kong: Macmillan.

[18] Pill, T. J. H. (2001). Adult learners’ perceptions of out-of-class access to English (MA thesis). Retrieved from http://sunzi.lib.hku.hk/hkuto/record/B3194517X

[19] Yap, S. S. L. (1998). Out-of-class use of English by secondary school students in a Hong Kong Anglo-Chinese school (MA thesis). Retrieved from

http://sunzi.lib.hku.hk/hkuto/record/B31944954

[20] Chik, A. (2007). From learner identity to learner autonomy: A biographical study of two Hong Kong learners of English. In P. Benson (Ed.), Learner autonomy 8: Teacher and learner perspectives (pp. 41-60). Dublin: Authentik Language Learning Resources. 
[21] Chan, V., Spratt, M., \& Humphreys, G. (2002). Autonomous language learning: Hong Kong tertiary students' attitudes and behaviours. Evaluation and Research Education, 16(1), 1-18.

[22] Reinders, H. (2014). Personal learning environments for supporting out-of-class language learning. English Teaching Forum, 52(4), 14-19.

[23] Naiman, N., Fröhlich, M., Stern, H. H., \& Todesco, A. (1996). The good language learner. Clevedon, England: Multilingual Matters.

[24] Chan, H. W. (2012). Learner autonomy, agency, and affordances: Multiple case studies of the out-of-class English learning of highly proficient university students in Hong Kong (Doctoral dissertation). The Chinese University of Hong Kong, Hong Kong.

[25] Chan, W. H. W. (2011). Learner autonomy and the out-of-class English learning of proficient students in Hong Kong. The International Journal of Learning, 17(11), 45-62.

[26] Hood, M. (2009). Case study. In J. Heigham \& R. A. Croker (Eds.), Qualitative research in applied linguistics: A practical introduction (pp. 66-90). Hampshire: Palgrave Macmillan.

[27] Pavlenko, A. (2007). Autobiographic narratives as data in applied linguistics. Applied Linguistics, 28(2), 163-188.

[28] Sydorenko, T. (2010). Modality of input and vocabulary acquisition. Language Learning \& Technology, 14(2), 50-73.

[29] Trajtemberg, C., \& Yiakoumetti, A. (2011). Weblogs: a tool for EFL interaction, expression, and self-evaluation. ELT Journal, 65(4), 437-445.

[30] Reinders, H. (2011). Materials development for learning beyond the classroom. In P. Benson \& H. Reinders (Eds.), Beyond the language classroom (pp.175-189). Basingstoke, Palgrave Macmillan.

[31] Chik, A., \& Breidbach, S. (2011). Online language learning histories exchange: Hong Kong and German perspectives. TESOL Quarterly, 45(3), 553-564.

[32] Little, D. (2011). Learner autonomy, self-assessment and language tests: Towards a new assessment culture. In B. Morrison (Ed.). Independent language learning: Building on experience, seeking new perspectives (pp. 25-39). Hong Kong: Hong Kong University Press.

[33] Murphy, L. (2011). I’m not giving up! Maintaining motivation in independent language learning. In B. Morrison (Ed.). Independent language learning: Building on experience, seeking new perspectives (pp. 73-85). Hong Kong: Hong Kong University Press.

[34] Benson, P. (2009). Making sense of autonomy in language learning. In R. Pemberton, S. Toogood, \& A. Barfield (Eds.), Maintaining control: Autonomy and language learning (pp. 13-26). Hong Kong: Hong Kong University Press.

[35] Lantolf, J., \& Pavlenko, A. (2001). (S)econd (L)anguage (A)ctivity theory: Understanding second language learners as people. In M. P. Breen (Ed.), Learner contributions to language learning: New directions in research (pp. 141-158). Essex, Pearson. 